IJAAR IJAAR PUBLISHING DOI: 10.46654

International Journal of Advanced Academic Research (Sciences, Technology and Engineering) | ISSN: 2488-9849

Journal DOI: 10.46654/ij.24889849

Vol. 6, Issue 10 (October, 2020) | www.ijaar.org

\title{
ENVIRONMENTAL IMPACT OF RAVINE DEGRADATION ON SOCIO-ECONOMIC DEVELOPMENT IN NSUKARA OFFOT IN UYO LGA, AKWA IBOM STATE
}

\author{
Okereke M. O ${ }^{1}$, Uchua A. $\mathrm{K}^{2}$, Essien J. J ${ }^{3}$ and Ezugwu J. E
}

1. * Department of Space Education and Training, Advanced Space Technology Applications Laboratory, University of Uyo, P.M.B. 1223 Uyo, ogochux.mimi@gmail.com, +2348065127786

2. Advanced Space Technology Applications Laboratory, University of Uyo, P.M.B.1223 Uyo.

3. Department of Space Applications \& Research, Advanced Space Technology Applications Laboratory, University of Uyo.

4. Department of Space Education \& Training, Advanced Space Technology Applications Laboratory, University of Uyo.

\begin{abstract}
Ravine degradation is one of the major environmental threats throughout the world and affects multiple soils and land functions. There is ample physical evidence of severe gully erosion occurring in different parts of the world. Gullies are one of the few sources of morphological evidence in the landscape showing the intensity of soil erosion in the area, reflecting the impact of environmental change (especially due to interactions between geomorphological features, changes in land use, and extreme climatic events). The impacts of ravine erosion in Akwa Ibom State, Uyo in particular are enormous and are still creating a lot of menace ranging from loss of farmlands and properties, a threat to vegetation, effect on life among others. This paper discusses the use of space-based techniques to assess the impact of ravine erosion and its effects on socio-economic development of Nsukara Offot in Uyo L.G.A. In the study, the shapefile of Uyo was used to clip the study area from Landsat 8 (2018) in a GIS environment, the extracted images were processed using ArcGIS 10.4, Likelihood classification was carried out for 3 spectral bands corresponding to Band 5, Band 4 and Band 3 combination Near infrared, red, and green (NIR, $R, G)$. Spot 5 Image was also used to identify the interesting features in the area that is valuable for this research work. The features digitized were Built-up areas, Ravine, and Roads. The ArcGIS software version 10.4 was used to buffer the distance from the ravine to the different structures, other facilities, and one of the major roads in the area. Results from the field observations and measurements showed that the width of the ravine is $8 \mathrm{~m}$, depth is $13 \mathrm{~m}$ while the length is about 100m. The distance of the ravine from the nearest building which is Ray Field International Secondary School, Uyo is $10 \mathrm{~m}$ away from the school gate and $5 \mathrm{~m}$ from the road. This shows a rapid encroachment to the facility and poses a hazard to both human and infrastructure. The study shows that the ravine occurred as a result of inappropriate channeling of water runoff in unprotected land thereby washing away the soil along the drainage line. GIS is a valuable tool in monitoring morphology while the results of the study can be used for planning for further monitoring, gully erosion control, and management.
\end{abstract}

Keywords: GIS, Ravine degradation, Morphology, environmental threat. 


\section{INTRODUCTION}

Ravine degradation is a major environmental threat throughout the world and affects multiple soils and land functions. There is ample physical evidence of intense gully erosion occurring at various times in the past in different parts of the world. Ravines are one of the few sources of morphological evidence in the landscape of past phases of intense soil erosion, reflecting the impact of environmental change (especially due to interactions between geomorphological features, changes in land use, and extreme climatic events). Ravine is one of many natural processes that shape the surface of the earth and represents a manifestation of catchment instability. It is only when gullies threaten humankind that they represent a hazard.

Ravine erosion occurs as a result of water cutting down into the soil along with the line flow. Ravine erosion is said to take place when excessive surface runoff flowing with high velocity and detach and carry soil particles down the slope. They may also occur when runoff volume from a steep increase sufficiently or increase in flow velocity to cut a deep hole along in path (Ehiorobo and Izinyon, 2011) It can also develop in traces formed by the movement of machinery down the slope. It can also occur when water is channeled across unprotected land and washes away the soil along the drainage lines. Under natural conditions, run-off is moderated by vegetation which generally holds the soil together, protecting it from excessive run-off and direct rainfall. Excessive clearing, inappropriate land use, and compaction of the soil caused by grazing often mean the soil is left exposed and unable to absorb excess water. Surface run-off then increases and concentrates in drainage lines, allowing gully erosion to develop in susceptible areas.

Many of the gullies within the urban landscape in Nigeria were formed mainly as a result of improper termination of drains and watercourse; land-use changes have caused the development of bank gullies along some river banks. Changes in drainage patterns associated with urbanization result in Gullying, particularly where illegal settlements without urban infrastructure exist. Ravine processes are usually the main sources of sedimentation (Hum et al, 2005). Ravines have three-dimensional nature affected by a variety of factors and processes which include surface hydrology soil, topography, and land use. Research carried out by various interest groups has shown that Ravine erosion is one of the driving forces of the soil degradation process in Nigeria as it causes considerable soil loss and produces a large volume of sediment. The total land area subjected to human-induced soil erosion is estimated at 2 billion hectares. By this, the land area affected by soil degradation is estimated at $110 \mathrm{Mha}$ by water erosion and 550Mha by wind erosion (Saha, 2003). Excessive soil erosion with decreased fertility has become a dignified environmental problem for the state.

Ravines are also a catalyst for transferring surface run off and sediment from upland to valley floors and creating up channels that aggravate the problem of flooding and water pollution. The study has shown that some cases of damages to watercourses and properties by runoff from agricultural land relate to the occurrence of Gully erosion (Verstraeten and Poesen, 1999, Bourdman, 2001, Poesen et al, 2003). Thomas et al, 2004, Valentin, Peosen and Li 2005), have shown that many gullies grow initially rapidly to large dimensions making effective control technically difficult or prohibitively expensive. This is why studies on Gully processes (Gomez et al, 2003) and their modeling (Siderchuk, 2005) are scarce. The impacts of ravine erosion in 
Akwa Ibom State, Uyo in particular are enormous and are still creating a lot of menaces, they include Loss of Farmland: Ravine erosion has created and is still creating a lot of menaces. A vast area of farmlands has been lost due to the menace of gully erosion while others are at their various stages of destruction leading to a drastic decrease in agricultural productivity and ultimately food shortage that can lead to famine.

A threat to Vegetation: The gully erosion in Nigeria has resulted in the loss of vegetation as its continuous expansion encroaches into areas that are hitherto forest leading to falling of trees and exposure of more surface areas to gully activities. The phenomenon if allowed to continue and remains unchecked may ultimately lead to climatic changes locally or globally.

Effect on Properties: Several properties whose value cannot be quantified accurately here have been destroyed and others are under threat by this menace especially houses and other properties located on the floodplain. Apart from untimely evacuation from these gully sites, infrastructural facilities such as pipelines, utility cables, roads, and houses also suffer from these hazardous events.

A threat to Life: Many lives have been lost as a result of the problem of ravine erosion. Sometimes, people either fell into these gullies and sustained various degrees of injury or died. Some instances have also been reported where people are drowned in some of the gully sites. Millions of people have been displaced and evacuated their homes following the gully incidences.

Isolation of Villages and Towns: Ravine erosion has resulted in the separation of adjacent villages and towns as it may involve the collapse of the bridges linking them together. This has had negative impacts on such areas since some facilities such as schools, hospitals and water supplies shared by the affected neighboring communities may become inaccessible. Transportation of farm produce has also been affected and this also often leads to loss of agricultural products especially the perishable ones. Traders who also go to these areas for their trade are also cut off from their normal day-to-day business.

Bad Land: Ravine erosion has given rise to the infertile and barren land that may need to be reclaimed. This usually brings untold hardship to the inhabitants if the land is still inhabitable but has been severely affected. 
International Journal of Advanced Academic Research (Sciences, Technology and Engineering)| ISSN: 2488-9849 Vol. 6, Issue 10 (October, 2020) | www.ijaar.org

Journal DOI: 10.46654/ij.24889849

Article DOI: 10.46654/ij.24889849.e61027
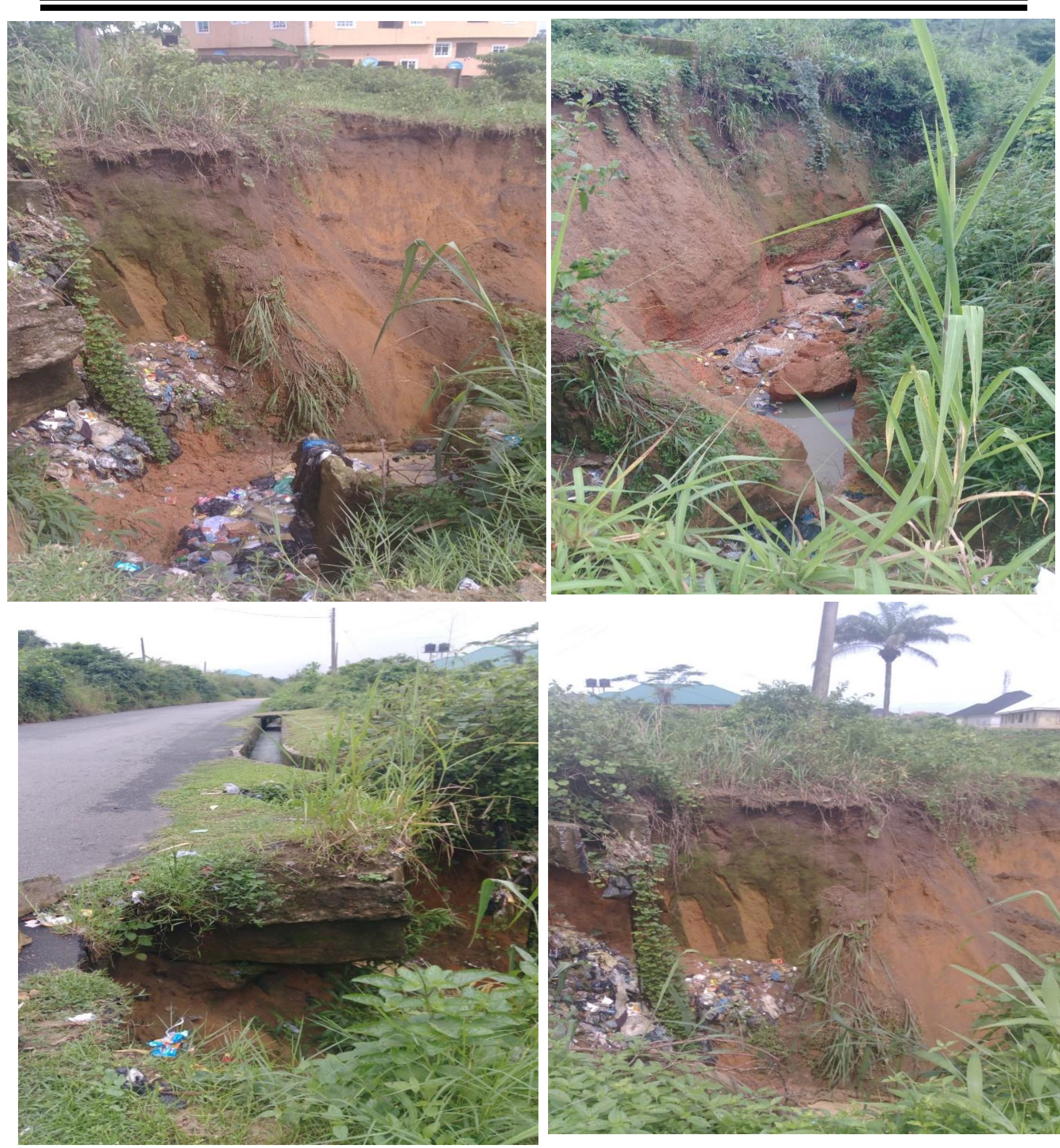

Plate 1: showing ravine erosion. 


\section{METHODOLOGY}

The use of space-based techniques offers the potential to effectively measure Ravine volume at the landscape scale. Monitoring and experimental studies of the initiation and development of gullies at various temporal and spatial scales need to be carried out. In the current study, the Global Positioning System (GPS) device was used to establish the coordinates and superimposed on both Landsat 8 and SPOT 5 imageries to ascertain the features of the study area.

\section{The study area}

The Vision road ravine erosion is located within 31 UTM North Eastern of Uyo, the Akwa Ibom state capital. The study area is bounded by the coordinate of N $05^{\circ} 01^{\prime} 57.5^{\prime \prime} \mathrm{E} 007^{\circ} 59^{\prime} 04.7^{\prime \prime}$. The main Ravine run in a southeasterly direction. The relief consists of undulating and low-lying rolling topography. The most prominent feature of the physical landscape of Uyo is the ravine lying north-easterly of the town. Slopes of $6^{\circ} 8^{\prime}$ are common on the Interfluves and deep ravines. The study has Temperature regimes of humid and ranges between $26 \mathrm{oC}$ and $35 \mathrm{oC}$ with an annual temperature of $28.4 \mathrm{oC}$ (Ukpong, 2009).

MAP OF UYO L.G. A,SHOWING THE STUDY AREA

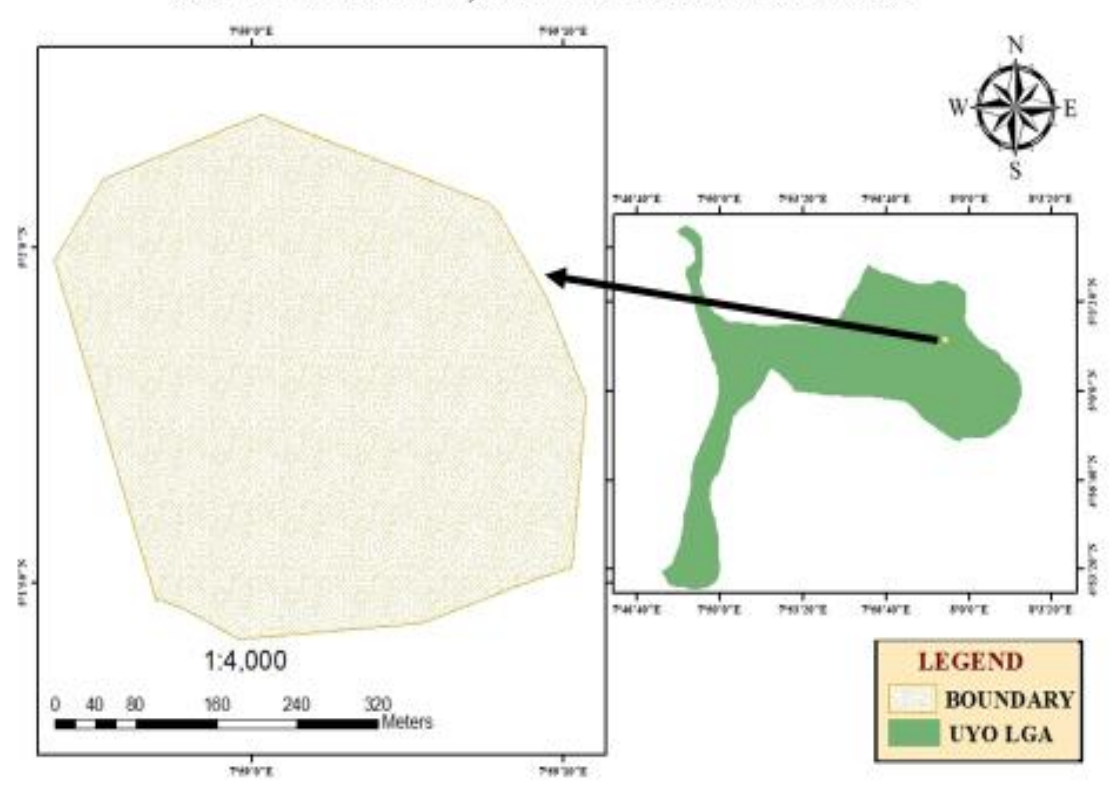

Fig. 1 showing a map of the Study Area

The Study area experiences a tropical climate and is characterized by two seasons, namely, the rainy season and the dry season. The study area receives relatively higher rainfall totals than other southern parts of the country. The rainy season begins about March/April and lasts until mid-November. The dry season begins in mid-November and ends in March. As a result of the proximity of the study area to the ocean, the harmattan dust haze is not usually too severe as in the northern part of Nigeria. Temperature values are relatively high in the state throughout the 
year, with the mean annual temperatures varying between about $26^{\circ} \mathrm{C}$ to $36^{\circ} \mathrm{C}$. The study area has relative humidity that varies between 75 percent to 95 percent, with the highest and lowest values in July and January respectively.

\section{FIELD SURVEY/ MESUREMENT}

A topographical survey of the study area was carried out using a combination of a GPS receiver and a measuring tape. The shapefile of Uyo was used to clip the study area from Landsat 8 (2018) in the GIS environment. The extracted images were processed using ArcGIS 10.4. Likelihood classification was carried out for 3 spectral bands corresponding to Band 5, Band 4, and Band 3 combination Near infrared, red, and green (NIR, R, G) for LandSat 8 (2018).

The land use and land cover classes identified in images were classified into;

\section{$\checkmark$ Built-up \\ $\checkmark$ Dense Vegetation \\ $\checkmark$ Light Vegetation}

Spot 5 Image used was georeferenced and digitized in ArcGIS word to identify the interesting features in the area that is valuable for this research work. The features digitized were Built-up areas, Ravine, and Roads. The ArcGIS software version 10.4 was used to buffer the distance from the ravine to the different buildings and other facilities and one of the major roads in the area. Drone pro-technology was also used to capture and analyze the area and depth of the Ravine erosion. Arc GIS was further used for developing the raster GIS for the soil loss computations (the parameters models are $-\mathrm{R}, \mathrm{K}, \mathrm{LS}, \mathrm{C}, \mathrm{P}$ )

\section{RESULTS AND DISCUSSION}
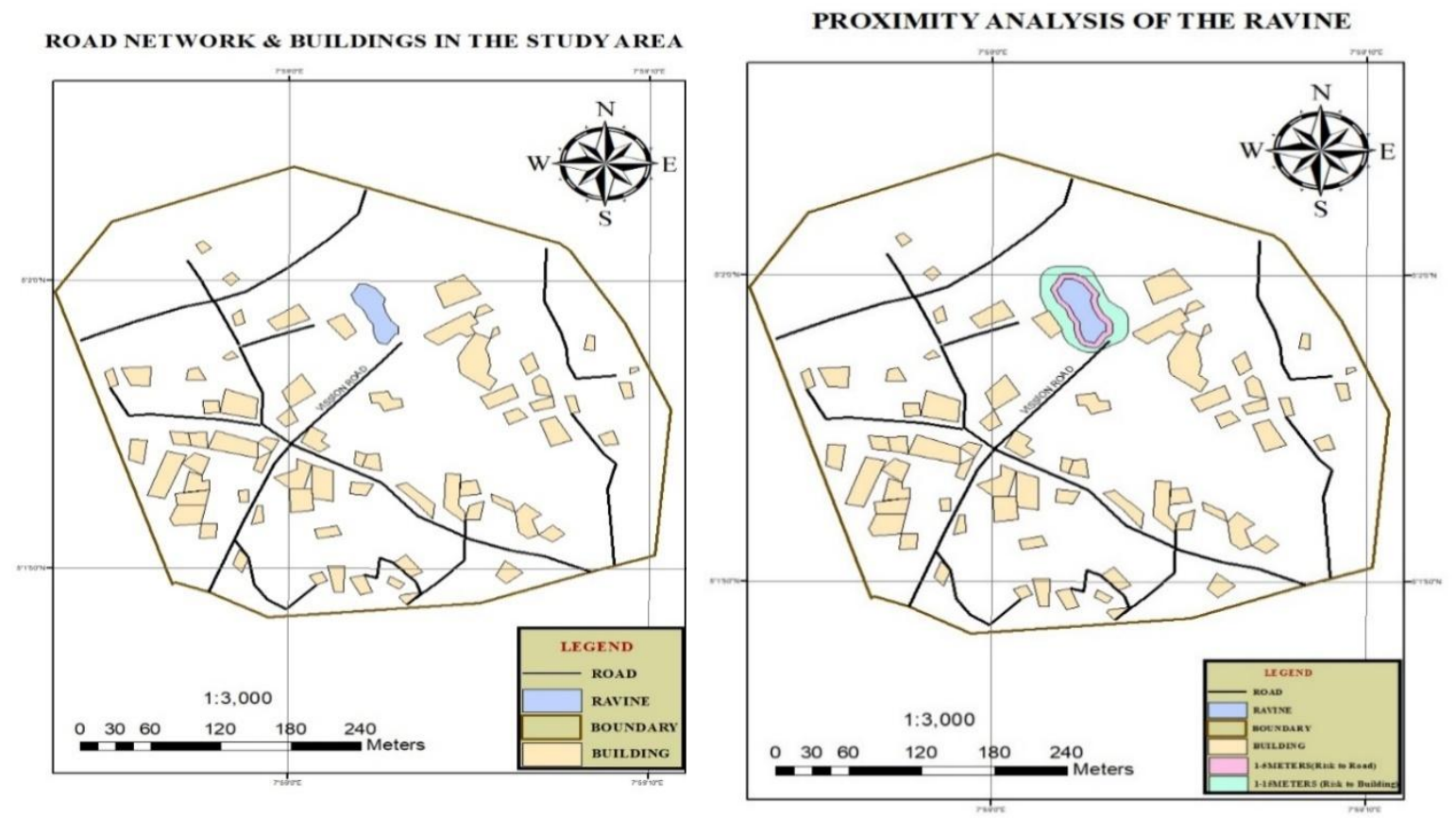

Fig 2 and 3: showing Road Network, surrounding buildings, and proximity analysis map 
Buffering was done at different distances to show the rate of encroachment of ravine in the study area. Fig. 3 shows the buffer map at a distance of $10 \mathrm{~m}$ to the nearest residential building. This shows that the menace of ravine erosion requires urgent attention. The buffering serves as a tool for checking the rate of encroachment in the study area. It also helps to determine erosion hotspot and possible affected site or structure.

\section{SOIL EROSION RISK ASSESSMENT METHODOLOGY:}

Soil loss is a very critical determinant factor in erosion and ravine degradation. In this work, it was important to assess the level of soil loss in the study area to be able to ascertain the erosion severity of the area. The soil loss model, Revised Universal Soil Loss Equation (RUSLE) integrated with GIS has been used to estimate soil loss and to develop the erosion risk map.

RUSLE model parameters

$\mathrm{A}=\mathrm{R} \times \mathrm{K} \times \mathrm{LS} \times \mathrm{C} \times \mathrm{P}$

Rainfall erosivity factor $(\mathrm{R})$ : The $\mathrm{R}$ factor is a numerical value that reflects the effect of rainfall intensity on soil erosion. The erosivity value was derived using rainfall intensity and the location coordinates data collection point was used in the generation of the rainfall erosivity factor map of the study area using the formula:

$\mathrm{R}={ }^{\wedge}$

The coordinates and the $\mathrm{R}$ factor values were saved in an Excel format. The excel file was imported using the Add XY tool in ArcGIS 10.5 to generate the point map of the rainfall erosivity before interpolation. The 'Inverse Distance Weight' method of interpolation in ArcGIS was implemented to generate the R-Factor map.

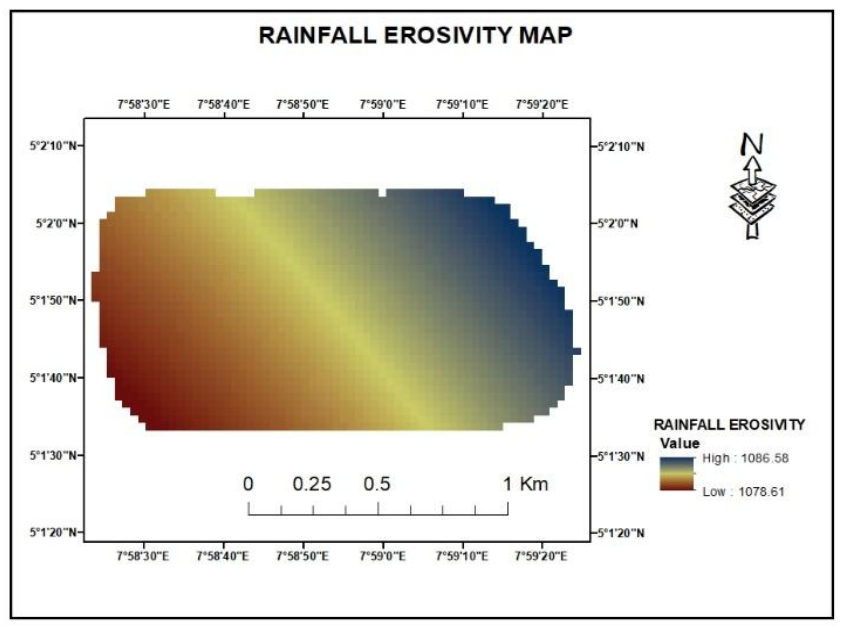

Fig 4: Showing Rainfall Erosivity 


\section{SOIL ERODIBILITY FACTOR (K):}

Soil Erodibility factor $(\mathrm{K})$ is the representation of soil susceptibility to erosion, transportability of the sediment, and the amount and rate of runoff given a particular rainfall input, as measured under a standard condition.

Clay soils have a low $\mathrm{K}$ value because these soils are resistant to detachment. Sandy soils are also having low $\mathrm{K}$ values due to high infiltration rates and reduced runoff, and because sediment eroded from these soils is not easily transported. Silt loam soils have moderate to high $\mathrm{K}$ values as the soil particles are moderate to easily detachable, infiltration is moderate to low producing moderate to high runoff, and the sediment is moderately to easily transport. Silt soils have the highest $\mathrm{K}$ values as these soils crust readily, producing high runoff rates and quantities.

The $\mathrm{K}$ factor is a numerical value that varies from 0 to 1 and was gotten after the soil test in which soil erodibility values closer to 0 are less prone to soil erosion. The erodibility value and the location coordinates of the sample point were used in the generation of the soil erodibility factor map of the study area. The input used is a point dataset such as the locational coordinate of the 5 soil sample points and $\mathrm{K}$ factor value gotten from the lab analysis. The coordinates and the $\mathrm{K}$ factor values were saved in an Excel format. The excel file was imported using the Add XY tool in ArcGIS 10.5 to generate the point map of the soil erodibility before interpolation.

The 'Inverse Distance Weight' method of interpolation in ArcGIS was implemented to generate the K-Factor map.

The value of the K-factor in the study area ranged from 0.07418 to 0.07468 tons. ha/MJ.mm. Areas with high K-Factor are most likely to be eroded.

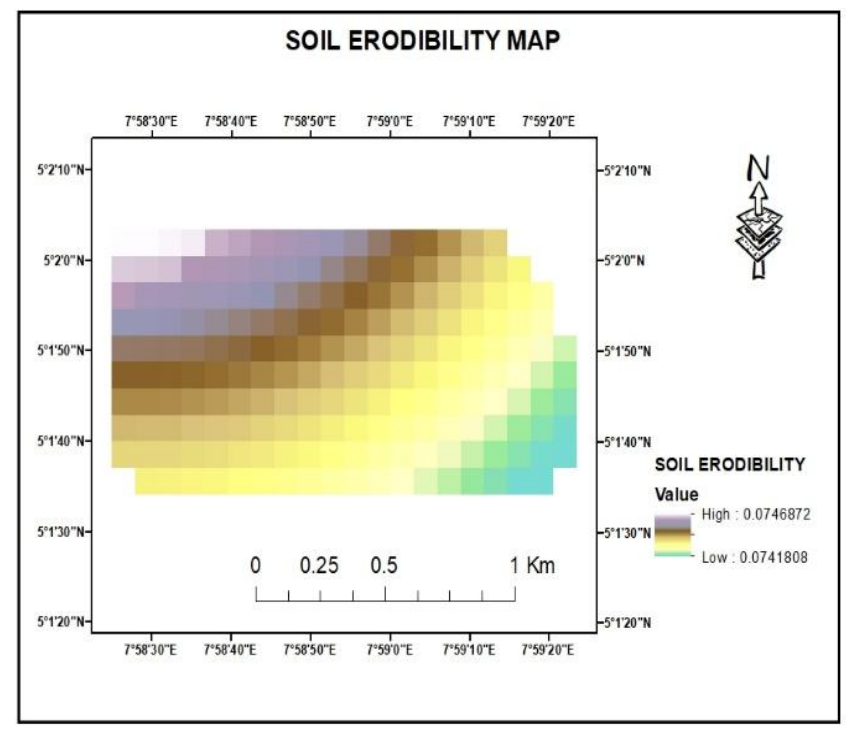

Fig 5: Soil Erodibility map 


\section{LS FACTOR:}

The combined LS factor indicates the effect of slope length and slope steepness on soil loss, and it may be calculated using different equations. In this study, the LS factor was computed using the Moore and Burch (1985) equation with the DEM as an input data. SRTM DEM data was used to get the slope steepness, slope length, and flow accumulation. Thus, the soil loss per unit area increases as the slope length increases.

The slope length is computed using the formula below:

$\mathrm{L}=(\mathrm{m}+1)(\lambda \mathrm{A} / 22.1) \mathrm{m}$

The value of $\mathrm{m}$ is derived based on the slope steepness.

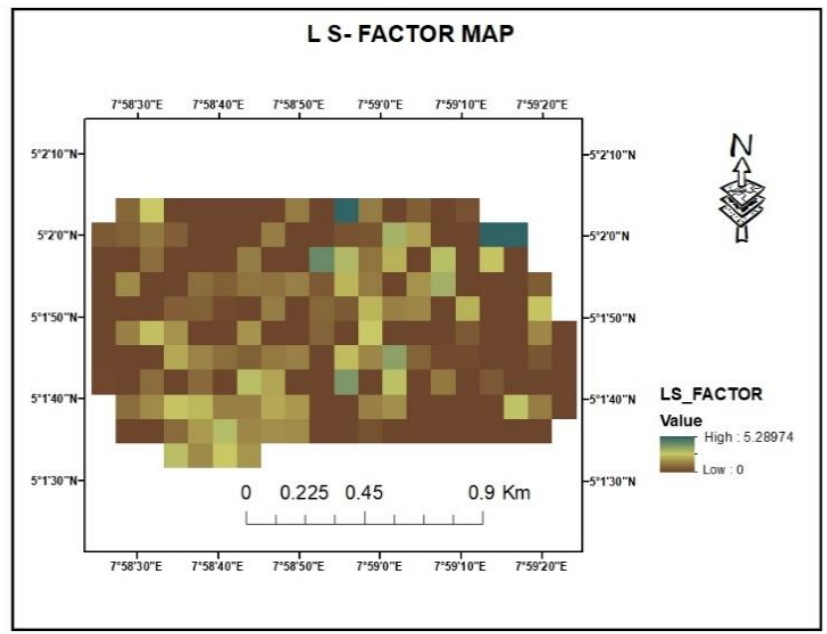

Fig 6: L S- Factor map

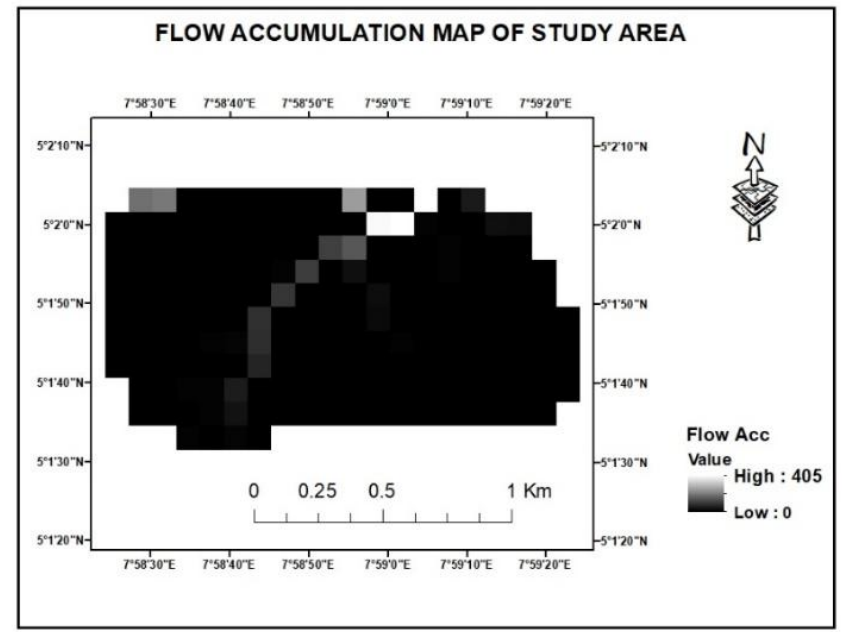

Fig 7: Flow accumulation map

\section{FACTOR:}

The Cover Management factor is another important parameter of the Universal Soil Loss Equation, this is because it measures the effect of all interrelated cover and management variables. It is defined as the ratio of soil loss under a given crop and management system to that of bare soil. C-factor ranges from 1 and almost $0, \mathrm{C}=1$ means no cover effect and a soil loss comparable to that from tilled bare fallow while $\mathrm{C}=0$ means a very strong cover effect resulting in no erosion. The crop management factor map (Fig. 9) was prepared based on the land use-land cover map of the study area. The land use land cover of the study area was classified with six land use-land cover classes, namely, farmland, forest area, built-up, shrub (Fig.8 based on the ground information. 

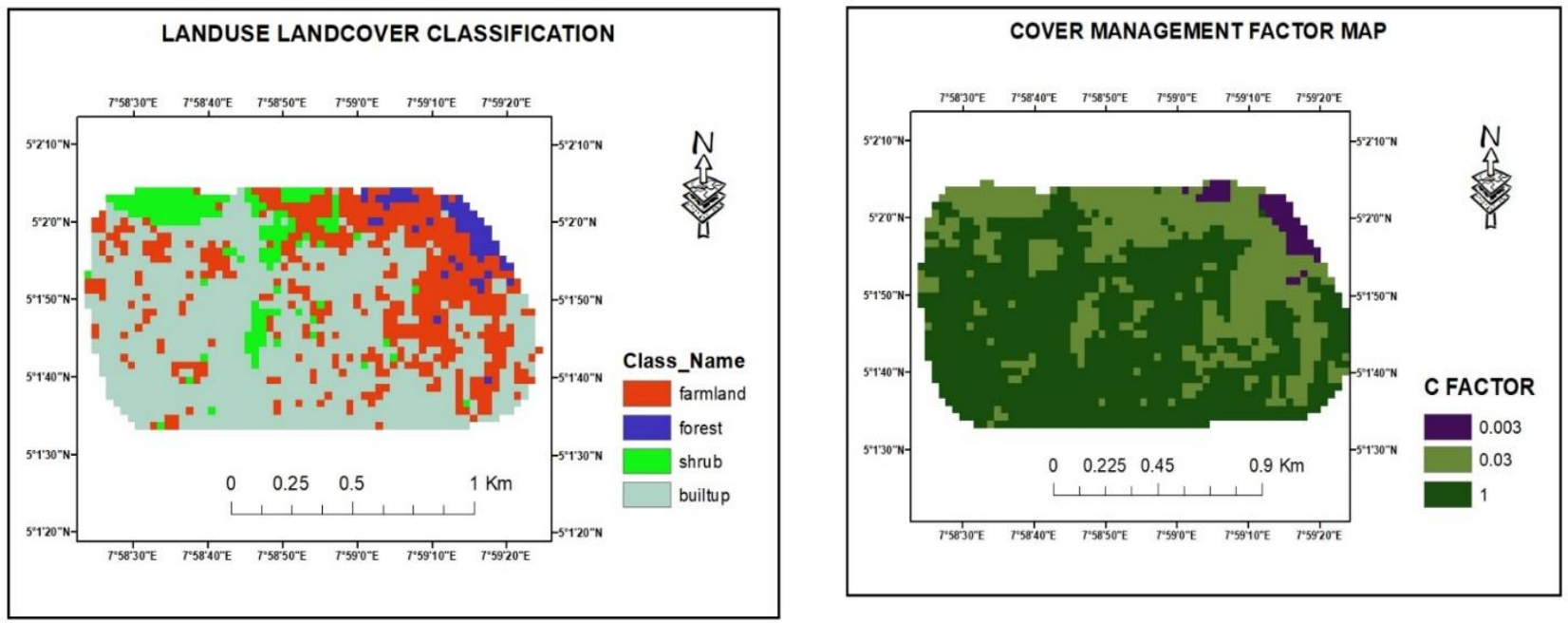

Fig 8: showing Land Use Land cover classification

Fig 9: Cover Management Factor

\section{EROSION RISK MAP}

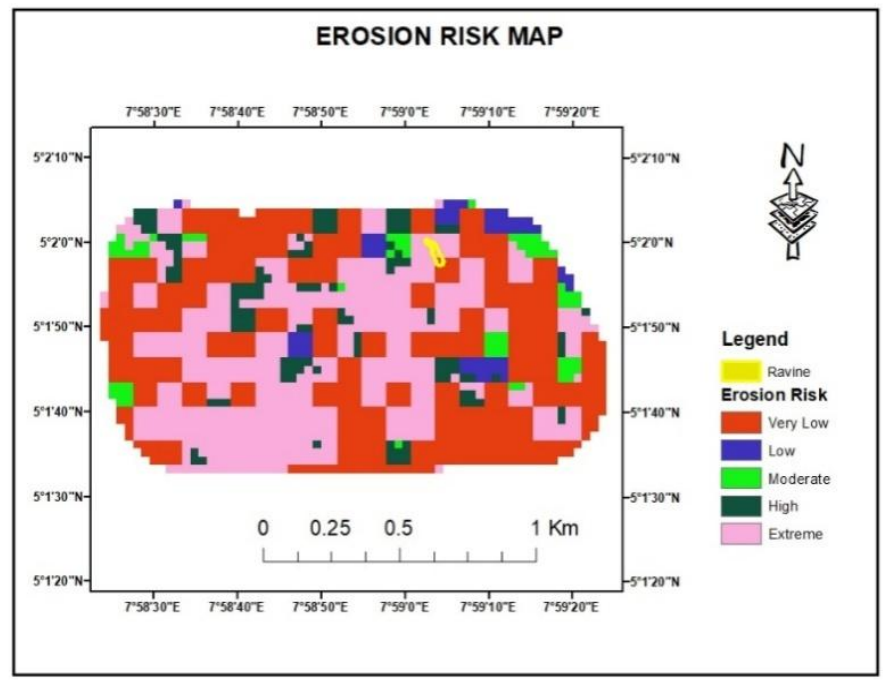

Fig 10: Showing erosion risk map

From the Erosion risk map, $45.55 \%$ represent area with very low soil loss, $3.5 \%$ - low, moderate $-3.9 \%$, High $-7.4 \%$ while extreme $-39.7 \%$ respectively. Therefore, it shows that the study area has extreme soil loss thereby making the area prone to ravine degradation. The ravine clearly falls within the area where there is extreme soil loss. 


\section{CONCLUSION}

Akwa Ibom and elsewhere in Nigeria suffer from the havocs of ravine erosion. The causes of Ravine erosion in Nigeria include both natural and anthropogenic sources. The impacts include loss of human and animal lives, loss of properties, and land resources. Some of the solutions that are proffered include improved farming techniques, cultural methods of ravine control, and enactment of laws against any activities that favor gully growth. The government at all levels in Nigeria and the stakeholders in environmental management such as the State Ministry of Environment and Federal Ministry of Environment should also sensitize Nigerians on the causes, impacts, and problems of ravine erosion. However, poor or lack of implementation of research findings and recommendations seem to hinder the complete evaluation of proposed solutions. For instance, in some cases where an effort is made, poor quality of work usually leads to even greater erosion, as in the case of road construction probably due to poor supervision, poor funding, and corruption.

Though we have little or no control over the natural causes of gully erosion especially those related to the underlying geology, the individuals and relevant stakeholders should discourage all practices that are capable of initiating or speeding the phenomenon in Nigeria. If all the suggested solutions are carefully looked into, it is believed that the incidence of ravine erosion in Nigeria would be drastically reduced and the security of the lives of Nigerians and their properties will be guaranteed. Space-based technologies are a valuable tool in monitoring morphology while the results of the study can be used for planning for further monitoring, gully erosion control, and management. 


\section{REFERENCES}

Adediji A., Tukur A. M., Adepoju K. A. (2010), Assessment of Revised Universal Soil Loss Equation (RUSLE), Kastina area, Kastina State of Nigeria using Remote Sensing (RA) and Geographic Information System (GIS). Iranica Journal of Energy and Environment 1 (3): 255- 264, ISSN 2079-2115.

Board man J (2001) "Storms, Floods and Soil Erosion in the South Douns, East Sussex" Autum and Winter 2000 -1, Geography Vol 86 (H) pp $346-355$

Casali, J., Gimenez, R \& Bennett, S 2009, 'Gully erosion processes: monitoring and modeling', Earth Surface Processes and Landforms, vol. 34, pp. 1839-1840.

Ehiorobo O.J. and Izinyon O.C. (2011) "Measurements and Documentation for flood and Erosion Monitoring and Control in the Niger Delta Region of Nigeria Proceedings", Fig working, week, Marrakech, Moroccao. Http//www.fig.net/2011.

Gibson, DJD 2006, Land degradation in the Limpopo Province, South Africa, Johannesburg, South Africa, University of the Witwatersrand, MScdissertation.

Gomez B, Banburg K, Marden M, Trustum N A, Peacock D.H, and Hoskin P.J (2003) "Gully Erosion and Sediment production" TC WeraroaStrem, New Zealand. Water Resources Vol 39(7) pp 1187.

Kim H.S. (2006). Soil Erosion Modelling Using RUSLE and GIS on the IMHA watershed, South Korea. Department of Civil Engineering, Colorado State University, Fort Collins, CO 80523, Spring 2006.

Pirie, 2009, Gully erosion mapping using SPOT 5 satellite imagery, Pretoria, South Africa, University of Pretoria, Honours research report.

Poessen J, Ngehtergaele J, Verstraeten G and Valentin C (2003) "Gully Erosion and Environmental Change: Importance and Research needs" Catena, Volume 50 pp91 - 133

Saha, S. K. 2003, Water and wind-induced Soil Erosion Assessment and monitoring using Remote Sensing and GIS in Satellite Remote Sensing and GIS Applications in Agricultural Meteorology, pp.318-330.

Siderchuk A (2005)" Stochastic Component in the Gully Erosion Modelling" Catena, Vol 63 Vol 63 pp $299-317$

Verstraten G and Poesen J (1999) "The Nature of Small Scale Flooding, Muddy Floods and Retention Pond Sedimentation in Central Belgium". Geomorphology 29: 275 - 292.

Stocking, M \& Murnaghan, N 2000, Land degradation - guideline for field assessment, Norwich: Overseas Development Group, England, University of East Anglia. 